\title{
The Influence of Gibberellic Acid and Different Irrigation Resources on Morphological, Quality and Yield Parameters of some Sweet Sorghum Varieties in New Reclaimed Area
}

\author{
Mohamed S. El-Kady ${ }^{1}$, Samar A.M. Helmy ${ }^{1}$ and Maha. M. El-Zeny ${ }^{1}$
}

\begin{abstract}
A field experiment was conducted in sandy soil at Wadi El-Natrun region, Egypt $\left(3^{\circ} 23^{\prime} 19.89^{\prime \prime} \mathrm{N}\right.$ latitude and $30^{\circ} 21^{\prime 41.06 "}$ E longitude) during 2018 and 2019 seasons to evaluate growth, quality, productivity and water use efficiently of four sweet sorghum varieties (Sorghum Bicolor L. Moench) under the influence of two types of irrigation sources (fish farm waste water and well ground water irrigation) in addition to study the effect of spraying three concentration of gibberellic acid (zero, 200 and 400 ppm). The results revealed that fish farm waste water irrigation was significantly more efficient than well ground water irrigation on vegetative characters (stalk length and diameters (cm)), yield (gross and stripped stalk yields (ton/fed)) and water use efficiency (WUE of gross and stripped yields $\left(\mathrm{kg} / \mathrm{m}^{3}\right)$ ) in both seasons. Vice versa, the irrigation by well ground water surpassed the irrigation by waste water fish farm in quality parameters (juice and syrup extraction \%) and (sucrose and purity \%), in addition significant increases were detected in vegetative characters, yield and water use efficiency by increasing gibberellic acid $\left(\mathrm{GA}_{3}\right)$ concentrations from zero up to 400 ppm during both seasons. On the other hand, quality parameters of sweet sorghum plants decreased by increasing gibberellic acid (GA3) concentrations from zero up to $400 \mathrm{ppm}$ in both seasons. Sweet sorghum AGSC3 variety over passed the other varieties with respect to stalk length and diameters $(\mathrm{cm})$, yields of gross and stripped stalks yield (ton/fed) and water use efficiency (WUE) of gross and stripped stalks yield $\left(\mathrm{kg} / \mathrm{m}^{3}\right)$ in both seasons. While, results showed that Ramada variety surpassed significantly the other studied varieties under this study in respect to juice and syrup extraction (\%) as well as sucrose and purity $(\%)$ in both seasons.
\end{abstract}

Keywords: fish farm waste water, gibberellic acid, new reclaimed area, sweet sorghum, water resources.

\section{INTRODUCTION}

Sweet sorghum (Sorghum bicolor L. Moench) is one of the most important multifunctional crops that can be used for bioethanol production as well as for syrup and animal feed (Dželetović and Djordje, 2015). Moreover, it is gaining prominence in many countries as an alternative for biofuel production (Godsey et al., 2012) due to its high production of lignocellulosic biomass and fermentable sugars (Whitfield et al., 2012). In addition to the economic benefits, sweet sorghum has relatively low input requirements with ability to grow on marginal conditions such as water deficits, water logging, salinity and alkalinity (Supriya Mathur et al., 2017). Yield and composition of sweet sorghum are affected by variety. Selection of the grown variety is one of the most important decisions in the production of sweet sorghum syrup. A good variety should be of a high content of total soluble solids in the juice and adapted to the environmental conditions.

Water for agriculture is critical to the future of global food security. However, the continued increase in demand for water by non-agricultural uses, such as urban and industrial uses, and greater concern for environmental quality have put the demand for irrigation water in a closer examination and threatened food security. Irrigation practices is fundamental for crop production in areas of inadequate water supply, because water is often one of the primary factors in any crop production, thus its management plays a vital role in the agricultural strategy due to the limited water resources and at the same time the land reclamation. (Fedoroff $e t$ al., 2010)

Therefore, limited water and agricultural land are problematic in Egypt, in addition to climate change, predictions of increase in temperature and decrease in rainfall in recent years. There are strategy that depends on modern methods and new sources of non-traditional irrigation. One of these sources using waste water of fish farms. Agri-aquaculture is a viable and environment friendly option for increase farmer's income and netreturn. Therefore, farmer owning fish pond, water source and agricultural land at one location should go for agri-aquaculture for optimum utilization of resources, better income and ecologically sustainable development (Ray et al., 2010). The total land area used for this kind of aquaculture is (361,326 feddans) with an annual production between 1.2 and 3.4 tones/fed. (Value-Chain Analysis of Egyptian Aquaculture, 2011). A Reuse waste water of fish farming as a new resource for irrigation and rich with organic matter can improve soil quality and crops productivity and reduce the total costs of fertilizers by adding minimum doses from

DOI: 10.21608/ASEJAIQJSAE.2019.62605

${ }^{1}$ Sugar Crops Res. Inst., Agric. Res. Centre, Giza, Egypt.

Received October 17, 2019, Accepted November 24, 2019 
mineral fertilizers and reduce the pollution in soil. Abdelraouf and Ragab (2017) found that the yield under waste water of fish farm (WWFF) was higher than the yield under the canal fresh water (IW) by 11 and $51 \%$ in 2014 and 8 and $38 \%$ in 2015 seasons.

There are different growth regulators that manifest physiological effects on crop growth, morphological development and improve yield under marginal conditions such as gibberellic acid. Gibberellic acid, also called Gibberellin $\mathrm{A}_{3}$, GA or $\mathrm{GA}_{3}$, is a very potent hormone whose natural occurrence in plants controls their development. Gibberellic acid has the ability of modifying the growth pattern by affecting the cell elongation and cell division, biosynthesis of enzymes, protein, and carbohydrates contents (Gupta and Chakrabarty, 2013 and Milne et al., 2013). The application of plant growth regulators $\left(\mathrm{GA}_{3}\right)$ can be useful not only to achieve the technological quality desired by the ethanol industry, but the quality needed for other purposes as forage. (Almodares et al., 2013) $\mathrm{GA}_{3}$ are compounds able to change the morphology and physiology of plants and can be applied at different times (Leite et al., 2011), depending on the grower purpose for the crop.

The findings of Mokadem et al. (1999) and Abo-El Wafa and Abo-El Hamd (2001) supported a great difference between various sorghum varieties in stalk diameter, height of stalk, number of internodes, yield and its components, juice and syrup quality parameters. Datta et al. (2012) showed that sweet sorghum juice of ICSV25274 variety contains 2.9 reducing sugars, $18.5 \%$ total sugar and $1.12 \%$ protein. Al-Labboudy et al. (2008) found significant variation among the used sweet sorghum varieties in brix, sucrose, purity and reducing sugars $\%$. Yield and composition of sweet sorghum are affected by variety. Selection of the grown variety is one of the most important decisions in the production of sweet sorghum syrup. A good variety should be of a high content of total soluble solids in the juice and adapted to the environmental conditions in the area.

The aim of this work is to investigate the influence of different sources of irrigation water combined with the effect of gibberellic acid $\left(\mathrm{GA}_{3}\right)$ concentrations as a plant growth regulator on growth, quality, yield and water use efficiency of sweet sorghum varieties in Wadi El-Natrun as a new reclaimed area in Egypt.

\section{MATERIALS AND METHODS}

A field experiment was carried out at the Research Station of Water Management Research Institute (NWRC), Wadi El-Natrun, Egypt (30²3'19.89" N latitude, 30²1'41.06" E longitude and Altitude $25.5 \mathrm{~m}$ ) during the two summer seasons of 2018 and 2019.

\section{Plant material and experimental site}

Four sweet sorghum (Sorghum bicolor L. Moench) varieties namely; AGSC3, Gkahron, Gukorcirok and Ramada were chosen for the present investigation which obtained from Agricultural Research Center (ARC). The experimental site has the following characteristics: The average mean temperature is $38.3 \mathrm{C}^{\circ}$ in the hottest month (July) and 19.3 $\mathrm{C}^{\text {o }}$ in the coldest month (Jan.). Annual mean relative humidity is $70 \%$. The soil texture was sandy soil with an average bulk density of 1.56 $\mathrm{gm} / \mathrm{m}^{3}$, field capacity $9.1 \%$ and $5.9 \%$ wilting point. The seeds were sown on $1^{\text {st }}$ week of May and harvest 120 days later in both seasons. Nitrogen fertilizer was ammonium nitrate $(33.5 \% \mathrm{~N})$ applied as recommended (80 kg. $\mathrm{N} / \mathrm{fed}$ ), as well as phosphorus fertilizer was applied in the form of ordinary superphosphate (15.5\% $\left.\mathrm{P}_{2} \mathrm{O}_{5}\right)$ as recommended $\left(15 \mathrm{P}_{2} \mathrm{O}_{5} \mathrm{~kg} / \mathrm{fed}\right.$ at seed bed preparation), whereas potassium fertilizer was added in the form of potassium sulfate $\left(48 \% \mathrm{~K}_{2} \mathrm{O} / \mathrm{fed}\right.$.) at the rate of $48 \mathrm{~kg} \mathrm{~K} \mathrm{~K}_{2} \mathrm{O} / \mathrm{fed}$. Other culture practices treatments, were applied as recommended by the Ministry of Agriculture and Land Reclamation.

The amount of irrigation water $\left(2358.72 \mathrm{~m}^{3} / \mathrm{fed}\right)$ was calculated at the depth of $56.6 \mathrm{~mm}$ for a period of 120 days, according to the following equation demonstrated by Israelsen and Hansen (1962).

$$
\mathrm{D}_{\text {aiw }}=\frac{\text { F.C. }-\theta 1}{100} \times \mathrm{Bd} \times \mathrm{d}
$$

Where: $D_{\text {aiw }}=$ Depth of irrigation water applied $(\mathrm{mm})$, F.C. $=$ Soil moisture content at field capacity by weight (\%), $\theta 1=$ Soil moisture content before irrigation by weight $(\%), \mathrm{Bd}=$ Bulk density $\left(\mathrm{gm} / \mathrm{cm}^{3}\right)$ and $\mathrm{d}=$ Soil depth $(\mathrm{mm})$

\section{Experimental design and treatments}

The experiment was set up in split-split plot design with 24 treatments and three replicates, each plot consisted of five rows. The plot area was $4 \times 3 \mathrm{~m}$. Drip irrigation system was used in the experiment, consist of pump, control unit, main line, and sub main line and laterals. The dripper types were GR with $4 \mathrm{lit} / \mathrm{hr}$. discharge and $25 \mathrm{~cm}$ between dippers to another. The main plots of the experiment were occupied by types of irrigation sources (well ground water (Table 1) and fish farm waste water (Table 2)). The gibberellic acid $\left(\mathrm{GA}_{3}\right)$ concentration $(0,200$ and $400 \mathrm{ppm})$ were distributed at random within the sub plots applied by spray Berelex after 30 days from sowing, while sweet sorghum varieties (AGSC3, Gkahron, Gukorcirok and Ramada) occupied randomly the sub-sub plots. 
Table 1. Chemical analysis of well irrigation water under study

\begin{tabular}{|c|c|c|c|c|c|c|c|c|c|c|}
\hline \multirow{2}{*}{$\mathbf{P}^{\mathrm{H}}$} & \multirow{2}{*}{ EC (ppm) } & \multicolumn{4}{|c|}{ Soluble anions (meq/l) } & \multicolumn{4}{|c|}{ Soluble cations (meq/l) } & \multirow{2}{*}{ SAR } \\
\hline & & $\mathrm{CO}_{3}{ }^{--}$ & $\mathrm{HCO}_{3}{ }^{-}$ & $\mathrm{Cl}^{-}$ & $\mathrm{SO}_{4}^{--}$ & $\mathrm{Ca}^{++}$ & $\mathbf{M g}^{++}$ & $\mathbf{N a}^{+}$ & $\mathbf{K}^{+}$ & \\
\hline 7.14 & 1200 & 0.1 & 4.7 & 10.6 & 8.15 & 1.8 & 2.8 & 18.4 & 0.55 & 12.1 \\
\hline
\end{tabular}

Table 2. Physical chemical and biological analysis of waste water of fish farm under study

\begin{tabular}{|c|c|c|c|}
\hline \multicolumn{2}{|c|}{ Physical determinant Value } & \multicolumn{2}{|c|}{ Biological determinant Counts (CFU/ml) } \\
\hline EC & $2500 \mathrm{ppm}$ & Total counts of bacteria & $1.5 \times 10^{4}$ \\
\hline $\mathrm{P}^{\mathrm{H}}$ & 7.02 & Total count of faecal coliform & $3 \times 10^{2}$ \\
\hline \multicolumn{2}{|c|}{ Chemical elements (ppm): } & Total counts of fungi & 500 \\
\hline $\mathrm{Cr}$ & 0.0 & Total counts of free N2 fixers & 600 \\
\hline $\mathrm{Cu}$ & 0.33 & \multicolumn{2}{|c|}{ Green algae: } \\
\hline $\mathrm{Ni}$ & 0.0 & Chlorella sp. Count & 400 \\
\hline $\mathrm{Zn}$ & 1.1 & Scenedesmus sp. Count & 150 \\
\hline $\mathrm{N}$ & 4.79 & Pediastrum sp. Count & 120 \\
\hline $\mathrm{P}$ & 10.2 & \multicolumn{2}{|c|}{ Cyanobacteria: } \\
\hline $\mathrm{K}$ & 35 & Oscillatoria sp. Count & 100 \\
\hline $\mathrm{Na}$ & 405 & Nostoc sp. Count & 50 \\
\hline
\end{tabular}

\section{Data recorded:}

Germination ratio: The germination ratio $\left(\mathrm{G}_{\mathrm{r}}\right)$ at each sub-sub plot at the age of 10 days from sowing was determined by using the following formula:

$$
\mathrm{G}_{\mathrm{r}}=\frac{\mathrm{N}_{\mathrm{p}}}{\mathrm{N}_{\mathrm{s}}} \times 100
$$

Where: $\mathbf{N}_{\mathbf{p}}=$ Number of plants within a length of $10 \mathrm{~m}$, $\mathbf{N}_{\mathrm{s}}=$ Number of seeds delivered within the same length.

Morphological characters: stalk length and diameter (cm) from the second row of each sub-sub plot were measured at the age of 90 days from sowing.

Yield: gross and stripped stalk yield (ton/fed) at harvest time (120 days from sowing) were determined by harvesting the $3^{\text {rd }}, 4^{\text {th }}$ and $5^{\text {th }}$ rows of each sub-sub plot, then the measured characters $/ \mathrm{m}^{3}$ convert to ton/fed.

\section{Quality parameters:}

1-Juice extraction \% was determined as follow: the stalks free from leaves and husks were passed through a three roller mill to extract the juice. The raw juice was screened through layers of clean cheesecloth to remove the large pieces of suspended matters, then Juice extraction \% was determined according to the following equation:

Juice extraction $\%=$ juice yield $($ ton/fed $) \times$ 100/stripped stalk yield (ton/fed)

2-Syrup extraction \% was determined as follow: the juice was evaporated in open stainless steel pan (capacity 6 liters). The concentration process was carried out as rapidly as possible, first using direct flame to boiling point, then, indirect using a hot plate (to TSS \% about $73 \%$ after cooling reached $75.00 \pm$
$0.50 \%)$. Then the syrup extraction \% were determined according to the following equation: Syrup extraction $\%=$ syrup yield (ton/fed) $\times$ 100/stripped stalk yield (ton/fed)

3-Sucrose \% was determined according to the methods described in A.O.A.C. (1995).

4-Purity $\%$ was determined by the following equation:

Purity $\%=$ Sucrose $\% \times 100 /$ TSS $\%$.

\section{Water use efficiencies (WUE)}

WUE was calculated according to Jensen (1983) formula as follows:

$$
\begin{aligned}
& \text { WUE }_{\text {gross }}=\frac{\text { gross yield }(\mathrm{kg} / \mathrm{fed})}{\text { Amount of water applied }\left(\mathrm{m}^{\mathrm{a}} / \mathrm{fed}\right)} \mathrm{kg} \\
& / \mathrm{m}^{\mathrm{a}} \\
& \text { WUE }_{\text {juice }}=\frac{\text { juice yield }(\mathrm{kg} / \mathrm{fed})}{\text { Amount of water applied }\left(\mathrm{m}^{\mathrm{a}} / \mathrm{fed}\right)} \mathrm{kg} \\
& / \mathrm{m}^{\mathrm{a}}
\end{aligned}
$$

Statistical analysis.

All data were subjected to the proper statistical analysis according to the procedures outlined by Gomez and Gomez (1984). Means of treatments were compared at the probability level of 5\% using the Least Significant Difference (LSD).

\section{RESULTS AND DISCUSSION}

\section{Germination ratio}

Concerning the germination ratio of varieties after 10 days from planting as shown in Fig (1), an observed difference between the evaluated varieties under the combination of treatments under study was detected during both seasons, whereas the germination ratio overcome in the second season compared to the first 
season for all varieties under study. AGSC3 and Gkahron varieties gave the highest mean values; while, Ramada variety showed the lowest one during the two successive seasons. These results are in agreement with that obtained by El-Geddawy, Dalia et al., (2014) who mentioned that the difference between verities led to the environmental conditions and gene extraction action, and because of the studied varieties grown in one location, then it could be concluded that the differences between the studied varieties mainly due to gene make up effect.

\section{Stalk length and diameter $(\mathrm{cm})$}

Data in Table (3) revealed that sweet sorghum irrigated by fish farm waste water significantly recorded higher values of stalk length and diameters $(\mathrm{cm})$ in the $1^{\text {st }}$ and $2^{\text {nd }}$ seasons, compared to that irrigated by well ground water. When irrigation sweet sorghum with fish farm waste water, stalk length exceeds by (109.05 and $109.67 \mathrm{~cm})$, as well as stalk diameter exceeds by $(0.91$ and $1.32 \mathrm{~cm}$ ) compared with well ground water during the $1^{\text {st }}$ and $2^{\text {nd }}$ seasons, respectively. Moursy (2018) indicated that the morphological measurements were highly enhanced by using agri-aquaculture (fish farm waste water) than ground water resource.

The results in Table (3) cleared that the sprayed of gibberellic acid $\left(\mathrm{GA}_{3}\right)$ concentrations had a significant influence on the stalk length and stalk diameter $(\mathrm{cm})$. Increasing gibberellic acid concentration up to $400 \mathrm{ppm}$ resulted in the highest values of these two traits, while decreasing it to 200 and $0 \mathrm{ppm}$ decreased stalk length and diameter by $(15.86$ and $37.24 \mathrm{~cm})$ and $(0.33$ and $0.62 \mathrm{~cm}$ ), respectively compared to that given at 400 $\mathrm{ppm}$, in the $1^{\text {st }}$ season. In the $2^{\text {nd }}$ one also, spraying plants by $400 \mathrm{ppm}$ was the appropriate gibberellic acid concentrations $\left(\mathrm{GA}_{3}\right)$, which attained (15.67 and 37.17 $\mathrm{cm}$ of stalk length) and $(0.40$ and $0.71 \mathrm{~cm}$ of stalk diameter), compared with that resulted by spraying 200 and $0 \mathrm{ppm}$, respectively. Similar effects of increasing stalk length and diameter $(\mathrm{cm})$ also observed in sweet sorghum crop under aerated conditions (Leite et al. 2011).

Data presented in Table (3) appeared significant differences between the examined sweet sorghum varieties in respect to stalk dimensions (stalk length and stalk diameters) in the two growing seasons. Sweet sorghum variety AGSC3 recorded the highest values of the above mentioned studied characteristics followed by Gkahron variety then Gukorcirok > Ramada in both seasons. It's well-known that the differences between the studied varieties mainly due to gene make up effect. These results are in line with that reported by Abo-El wafa and Abo-El Hamd (2001).

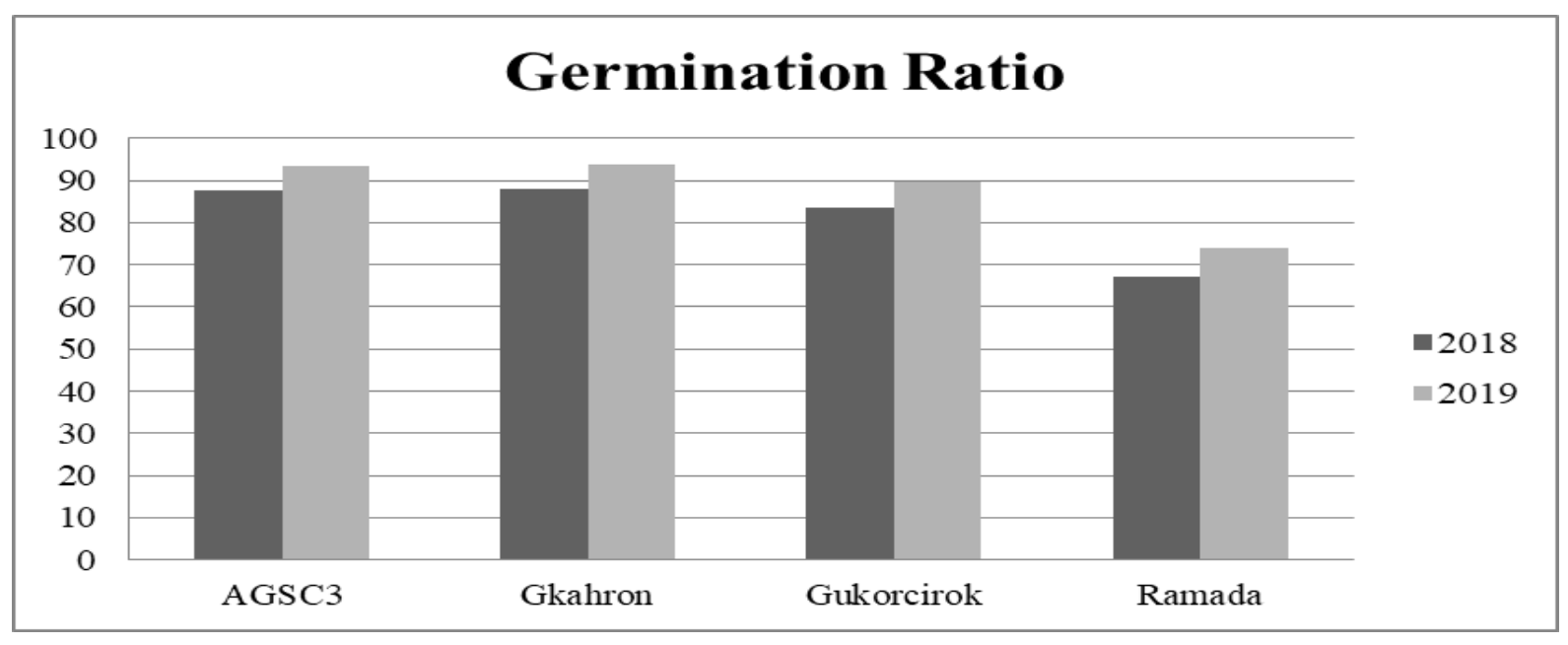

Fig. 1. Germination ratio of four sweet sorghum varieties during 2018 and 2019 seasons 
Table 3. Stalk length and diameters ( $(\mathrm{cm})$ of four sweet sorghum varieties under the effect of different irrigation resources types and gibberellic acid (GA 3 ) concentrations during 2018 and 2019 seasons

\begin{tabular}{|c|c|c|c|c|c|c|c|c|c|c|c|c|c|c|c|c|c|c|c|c|c|}
\hline \multirow[b]{3}{*}{$\begin{array}{l}\text { Sources } \\
\text { of } \\
\text { irrigation } \\
\text { (A) }\end{array}$} & \multirow[b]{3}{*}{$\begin{array}{c}\mathbf{G A}_{3} \\
\text { Conc* } \\
\text { (ppm) } \\
\text { (B) }\end{array}$} & \multicolumn{10}{|c|}{ Stalk length $(\mathbf{c m})$} & \multicolumn{10}{|c|}{ Stalk diameter $(\mathrm{cm})$} \\
\hline & & \multicolumn{5}{|c|}{2018} & \multicolumn{5}{|c|}{2019} & \multicolumn{5}{|c|}{2018} & \multicolumn{5}{|c|}{2019} \\
\hline & & 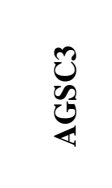 & 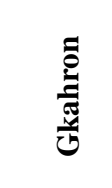 & 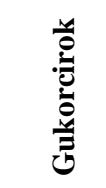 & 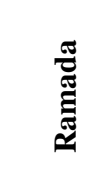 & 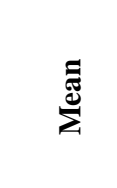 & 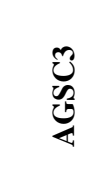 & 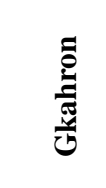 & 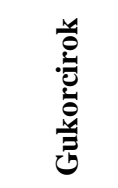 & 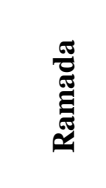 & 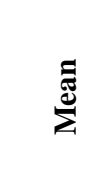 & 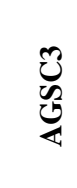 & 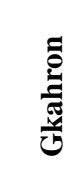 & 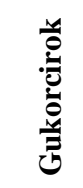 & 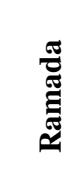 & 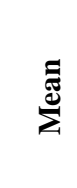 & 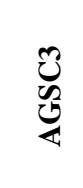 & 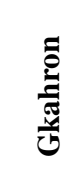 & 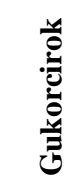 & 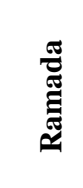 & 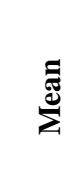 \\
\hline \multirow{3}{*}{ Aquaculture } & 400 & 274.40 & 259.80 & 256.90 & 251.40 & 260.63 & 285.28 & 270.71 & 267.75 & 262.28 & 271.51 & 2.3 & 2.17 & 2.1 & 1.96 & 2.13 & 3.04 & 2.91 & 2.84 & 2.65 & 2.86 \\
\hline & 200 & 250.30 & 248.00 & 241.50 & 237.80 & 244.40 & 261.21 & 258.81 & 252.35 & 248.71 & 255.27 & 1.83 & 1.7 & 1.7 & 1.53 & 1.69 & 2.41 & 2.28 & 2.28 & 2.11 & 2.27 \\
\hline & 0 & 232.30 & 227.90 & 210.20 & 200.60 & 217.75 & 242.93 & 238.53 & 220.8 & 211.2 & 228.37 & 1.53 & 1.27 & 1.2 & 1.07 & 1.27 & 2.11 & 1.85 & 1.78 & 1.65 & 1.85 \\
\hline \multirow[t]{2}{*}{ Mean } & & 252.33 & 245.23 & 236.20 & 229.93 & 240.93 & 263.14 & 256.02 & 246.97 & 240.73 & 251.71 & 1.89 & 1.71 & 1.67 & 1.52 & 1.70 & 2.52 & 2.35 & 2.30 & 2.14 & 2.33 \\
\hline & 400 & 151.4 & 150.3 & 142.4 & 146.2 & 147.58 & 161.28 & 160.18 & 152.31 & 156.11 & 157.47 & 1.1 & 0.97 & 0.9 & 0.97 & 0.99 & 1.33 & 1.2 & 1.13 & 1.2 & 1.22 \\
\hline \multirow[t]{2}{*}{ Well } & 200 & 139.4 & 134.2 & 128.9 & 125.8 & 132.08 & 149.67 & 144.47 & 139.27 & 136.07 & 142.37 & 0.87 & 0.87 & 0.65 & 0.7 & 0.77 & 1.1 & 1.1 & 0.88 & 0.93 & 1.00 \\
\hline & 0 & 124.7 & 114.5 & 115.1 & 109.6 & 115.98 & 134.97 & 124.8 & 125.4 & 119.9 & 126.27 & 0.6 & 0.7 & 0.67 & 0.5 & 0.62 & 0.79 & 0.89 & 0.86 & 0.69 & 0.81 \\
\hline \multicolumn{2}{|c|}{ Mean } & 138.50 & 133.00 & 128.80 & 127.20 & 131.88 & 148.64 & 143.15 & 138.99 & 137.36 & 142.04 & 0.86 & 0.85 & 0.74 & 0.72 & 0.79 & 1.07 & 1.06 & 0.96 & 0.94 & 1.01 \\
\hline $\mathrm{GA}_{3}$ & 400 & 212.90 & 205.05 & 199.65 & 198.80 & 204.10 & 223.28 & 215.45 & 210.03 & 209.20 & 214.49 & 1.70 & 1.57 & 1.50 & 1.47 & 1.56 & 2.19 & 2.06 & 1.99 & 1.93 & 2.04 \\
\hline$x$ & 200 & 194.85 & 191.10 & 185.20 & 181.80 & 188.24 & 205.44 & 201.64 & 195.81 & 192.39 & 198.82 & 1.35 & 1.29 & 1.18 & 1.12 & 1.23 & 1.76 & 1.69 & 1.58 & 1.52 & 1.64 \\
\hline Varieties & 0 & 178.50 & 171.20 & 162.65 & 155.10 & 166.86 & 188.95 & 181.67 & 173.10 & 165.55 & 177.32 & 1.07 & 0.99 & 0.94 & 0.79 & 0.94 & 1.45 & 1.37 & 1.32 & 1.17 & 1.33 \\
\hline Mean & & 195.42 & 189.12 & 182.50 & 178.57 & 186.40 & 205.89 & 199.58 & 192.98 & 189.05 & 196.87 & 1.37 & 1.28 & 1.20 & 1.12 & 1.24 & 1.80 & 1.71 & 1.63 & 1.54 & 1.67 \\
\hline \multicolumn{22}{|c|}{$\begin{array}{l}\text { L.S.D at } 0.05 \text { level } \\
\text { for: }\end{array}$} \\
\hline \multicolumn{2}{|l|}{ (A) } & & & & & 1.08 & & & & & 1.08 & & & & & 0.17 & & & & & 0.18 \\
\hline \multicolumn{2}{|l|}{ (B) } & & & & & 0.93 & & & & & 0.93 & & & & & 0.05 & & & & & 0.05 \\
\hline \multicolumn{2}{|c|}{ Varieties (C) } & & & & & 1.76 & & & & & 1.76 & & & & & 0.07 & & & & & 0.07 \\
\hline \multicolumn{2}{|c|}{$\mathrm{A} \times \mathrm{B}$} & & & & & 1.31 & & & & & 1.31 & & & & & 0.07 & & & & & 0.06 \\
\hline \multicolumn{2}{|c|}{$\mathrm{A} \times \mathrm{C}$} & & & & & 2.48 & & & & & 2.48 & & & & & N.S & & & & & N.S \\
\hline \multicolumn{2}{|c|}{$\mathrm{B} \times \mathrm{C}$} & & & & & N.S & & & & & N.S & & & & & N.S & & & & & N.S \\
\hline \multicolumn{2}{|c|}{$\mathrm{A} \times \mathrm{B} \times \mathrm{C}$} & & & & & 4.30 & & & & & 4.30 & & & & & N.S & & & & & N.S \\
\hline
\end{tabular}


The interactions between all the studied factors declared that a significant effect on stalk length $(\mathrm{cm})$ was obtained in the two seasons except for the interaction between gibberellic acid and varieties $(B \times C)$. On the other hands, the interaction on stalk diameters was only significant between the sources of irrigation and gibberellic acid $\left(\mathrm{GA}_{3}\right)$ concentration $(\mathrm{A} \times \mathrm{B})$ in both seasons.

\section{Gross and stripped stalk yield (ton/fed)}

One of the main objectives of this study is to examine the changes in the gross and stripped stalk yield (ton/fed) of four sweet sorghum varieties using different sources types of irrigation and different gibberellic acid concentrations (ppm) as important in new reclaimed area.

A significant increase in the gross and stripped stalk yield amounted to 14.20 and 10.29 ton/fed accompanying the irrigation by fish farm waste water compared to well ground water was gained in the $1^{\text {st }}$ season, corresponding to 15.13 and 11.83 ton/fed in the $2^{\text {nd }}$ one, respectively (Table 4). These findings may be due to the additional amount of dissolved biological nitrogen and other nutrients inherent in waste water of fish farm. These results are in accordance with those obtained by Abdelraouf and Ragab (2017) how found that the yield under waste water of fish farm was higher than the yield under well ground water.

A given gross yield was significantly increased by 7.60 and 9.48 ton/fed with increasing gibberellic acid $\left(\mathrm{GA}_{3}\right)$ concentration from zero to $400 \mathrm{ppm}$, in the $1^{\text {st }}$ and $2^{\text {nd }}$ seasons, successively. On the same trend, stripped stalk yield (ton/fed) was significantly increased by 7.60 and 7.74 ton/fed with increasing gibberellic acid $\left(\mathrm{GA}_{3}\right)$ concentration from zero up to $400 \mathrm{ppm}$ in 2018 and 2019 seasons, respectively. Increasing gross and stripped yields as $\mathrm{GA}_{3}$ level was raised can be referred to the increase in quantitative traits (stalk length and stalk diameters) that can be attributed to their components or other traits contribute have a direct role them as shown previously in Table (3).

Data in Table 4, revealed a significant difference between the tested varieties in gross and stripped yield (ton/fed). Where, AGSC3 and Ramada variety gave the highest and lowest gross and striped stalk yield in both seasons, respectively. Where, AGSC3 variety overcome by (3.39 and 3.37) and (2.80 and 3.17) ton/fed of gross and stripped stalk yield in 2018 and 2019 season, respectively, compared to Ramada variety. Meantime, the highest yield varieties are distinguished with the highest stalk performance in terms of stalk length and diameter. In this connection, numerous reports showed that individual stalk performance and stalk yield differed greatly among sweet sorghum varieties and most variations are genetically (Abd El-Karim et al., 1999 and Saleh 2004).

Gross and stripped stalk yield (ton/fed) was significantly influenced by the interaction between irrigation water resources and gibberellic acid $\left(\mathrm{GA}_{3}\right)$ concentration in the $1^{\text {st }}$ and $2^{\text {nd }}$ seasons. However, the highest mean values of gross and stripped stalk yield under irrigation sweet sorghum by fish farm waste water and $\mathrm{GA}_{3} 400 \mathrm{ppm}$. Whereas the lowest ones obtained under well ground water irrigation and zero $\mathrm{GA}_{3}$. Meanwhile the interaction between $\mathrm{A} \times \mathrm{B}, \mathrm{B} \times \mathrm{C}$ and $\mathrm{A} \times \mathrm{B} \times \mathrm{C}$ were not significantly affected the gross and stripped stalk yield during both seasons of this study, these showed that water resources types and gibberellic acid concentration act independent on the pervious characters.

\section{Juice and syrup extraction (\%)}

Regarding to sources of irrigation water, data in Table 5 revealed that irrigated sweet sorghum by well ground water significantly recorded high value of juice and syrup extraction percentage compared to fish farm waste water irrigation by (4.85 and $3.00 \%$ in 2018) and (15.79 and $4.00 \%$ in 2019), respectively. These results are in agreement with those obtained by Abdelraouf and Hoballah, 2014.

It was apparent that the different $\mathrm{GA}_{3}$ concentrations were influenced significantly. The lowest juice and syrup extractions (\%) were noticed with $400 \mathrm{ppm}$ treatment. The maximum extractions among $\mathrm{GA}_{3}$ concentrations were recorded with $0 \mathrm{ppm}$ (control) treatment followed significantly by $200 \mathrm{ppm}$ treatments during both seasons.

A given juice extraction (\%) was significantly increased by 4.90 and 8.06 with decreasing concentration of gibberellic acid from 400 to $0 \mathrm{ppm}$ in the $1^{\mathrm{st}}$ and $2^{\text {nd }}$ season, respectively. Also, syrup extraction (\%) increased by 2.08 and 1.56 by decreasing from 400 to $0 \mathrm{ppm}$ of $\mathrm{GA}_{3}$ concentration, in the first and second season, respectively. Similar finding is reported by Leite et al., (2011)

Once more, juice extraction values of sweet sorghum stalks appeared insignificant difference between the tested varieties in the two seasons. Moreover, sweet sorghum syrup extraction (\%) revealed significant differences between the tested varieties in both seasons. AGSC3 variety produced the highest syrup extraction values with significant difference over Gkahron, Gukorcirok and Ramada varieties in both seasons. The differences between varieties with respect to their 
Table 4. Gross and stripped stalk yield (ton/fed) of four sweet sorghum varieties under the effect of different irrigation sources and gibberellic acid (GA3) concentrations during 2018 and 2019 seasons

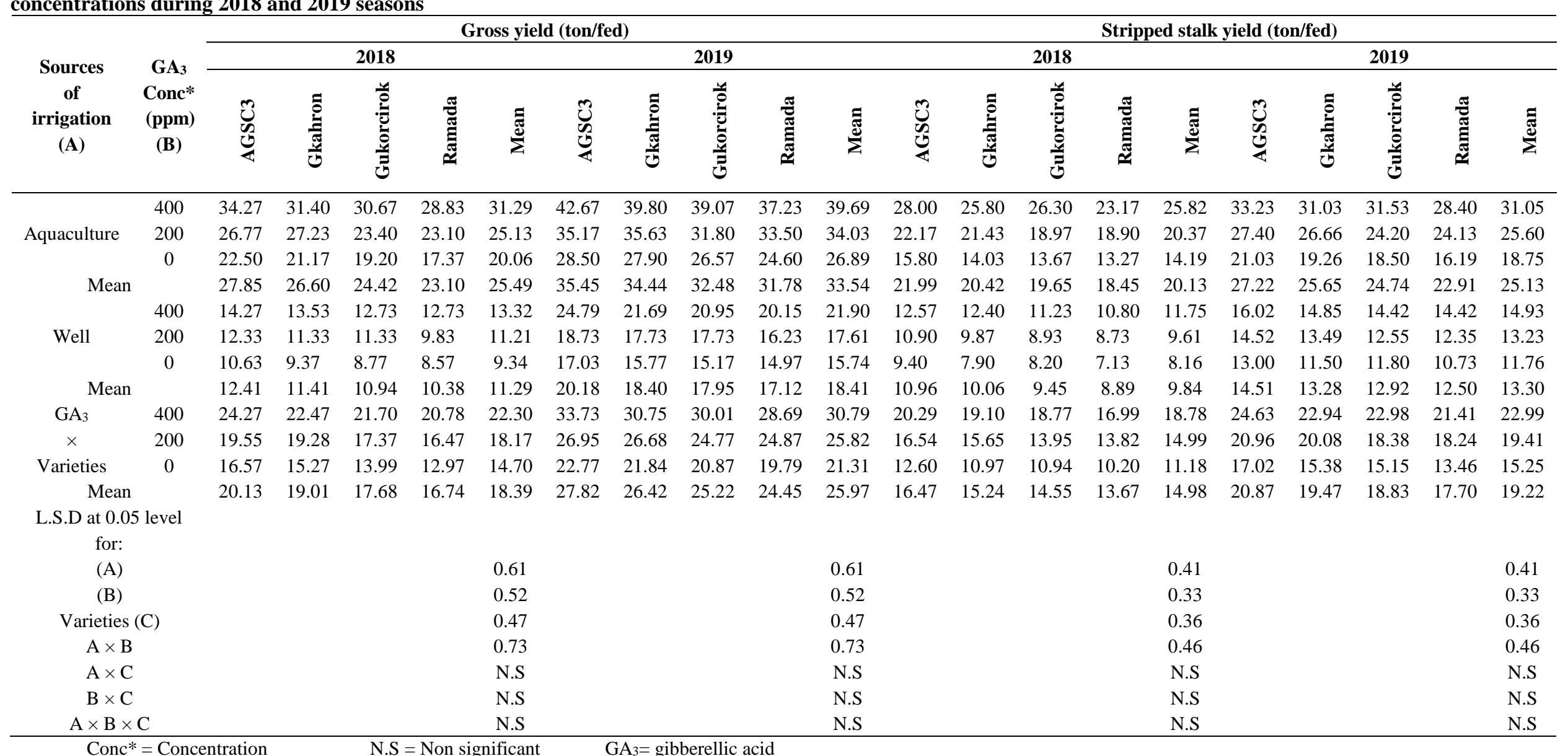


Table 5. Juice and syrup extraction (\%) of four sweet sorghum varieties under the effect of different irrigation sources and gibberellic acid (GA3) concentrations during 2018 and 2019 seasons

\begin{tabular}{|c|c|c|c|c|c|c|c|c|c|c|c|c|c|c|c|c|c|c|c|c|c|}
\hline \multirow[b]{3}{*}{$\begin{array}{l}\text { Sources } \\
\text { of } \\
\text { irrigation } \\
\text { (A) }\end{array}$} & \multirow[b]{3}{*}{$\begin{array}{c}\mathbf{G A}_{3} \\
\text { Conc* } \\
\text { (ppm) } \\
\text { (B) }\end{array}$} & \multicolumn{10}{|c|}{ Juice extraction (\%) } & \multicolumn{10}{|c|}{ Syrup extraction (\%) } \\
\hline & & \multicolumn{5}{|c|}{2018} & \multicolumn{5}{|c|}{2019} & \multicolumn{5}{|c|}{2018} & \multicolumn{5}{|c|}{2019} \\
\hline & & 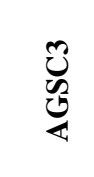 & 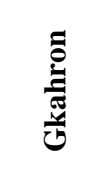 & 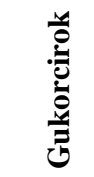 & 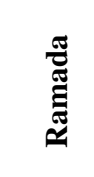 & $\stackrel{\Xi}{\Xi}$ & 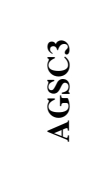 & 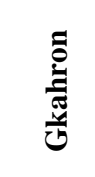 & 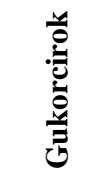 & 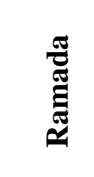 & 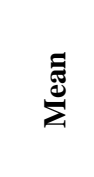 & 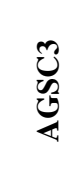 & 莞 & 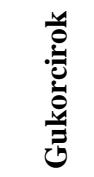 & 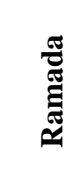 & 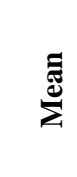 & 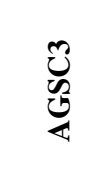 & 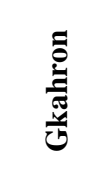 & 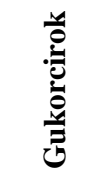 & 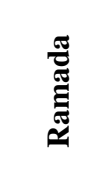 & 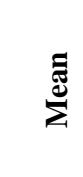 \\
\hline \multirow{3}{*}{ Aquaculture } & 400 & 24.78 & 25.91 & 27.17 & 28.92 & 26.70 & 29.69 & 31.23 & 32.18 & 34.56 & 31.92 & 4.15 & 4.46 & 4.30 & 5.39 & 4.58 & 4.96 & 5.67 & 5.44 & 7.08 & 5.79 \\
\hline & 200 & 34.80 & 32.38 & 34.34 & 31.52 & 33.26 & 37.39 & 35.51 & 37.78 & 35.47 & 36.54 & 5.29 & 5.17 & 6.95 & 6.62 & 6.01 & 7.25 & 7.35 & 9.56 & 9.32 & 8.37 \\
\hline & 0 & 38.28 & 42.55 & 41.07 & 39.28 & 40.30 & 44.98 & 49.72 & 51.72 & 45.48 & 47.98 & 7.62 & 8.51 & 8.58 & 8.88 & 8.40 & 7.62 & 8.80 & 8.96 & 9.31 & 8.67 \\
\hline \multirow[t]{2}{*}{ Mean } & & 32.62 & 33.61 & 34.19 & 33.24 & 33.42 & 37.35 & 38.82 & 40.56 & 38.50 & 38.81 & 5.69 & 6.05 & 6.61 & 6.96 & 6.33 & 6.61 & 7.27 & 7.99 & 8.57 & 7.61 \\
\hline & 400 & 41.57 & 36.04 & 44.89 & 34.16 & 39.17 & 52.73 & 54.45 & 52.97 & 58.73 & 54.72 & 9.27 & 9.37 & 9.70 & 9.36 & 9.43 & 11.02 & 11.14 & 11.89 & 11.65 & 11.43 \\
\hline \multirow[t]{2}{*}{ Well } & 200 & 36.74 & 43.96 & 41.91 & 38.58 & 40.30 & 48.68 & 54.59 & 56.79 & 57.06 & 54.28 & 8.46 & 9.09 & 9.04 & 8.62 & 8.80 & 10.84 & 11.82 & 12.23 & 12.01 & 11.73 \\
\hline & 0 & 36.58 & 37.37 & 31.38 & 36.09 & 35.36 & 55.42 & 56.29 & 51.08 & 56.35 & 54.79 & 9.02 & 10.21 & 11.06 & 8.73 & 9.76 & 10.50 & 12.13 & 12.70 & 11.36 & 11.67 \\
\hline \multicolumn{2}{|c|}{ Mean } & 38.30 & 39.12 & 39.39 & 36.28 & 38.27 & 52.28 & 55.11 & 53.61 & 57.38 & 54.60 & 8.92 & 9.56 & 9.93 & 8.90 & 9.33 & 10.79 & 11.70 & 12.27 & 11.67 & 11.61 \\
\hline $\mathrm{GA}_{3}$ & 400 & 33.18 & 30.98 & 36.03 & 31.54 & 32.93 & 41.21 & 42.84 & 42.58 & 46.65 & 43.32 & 6.71 & 6.92 & 7.00 & 7.38 & 7.00 & 7.99 & 8.41 & 8.67 & 9.37 & 8.61 \\
\hline$\times$ & 200 & 35.77 & 38.17 & 38.13 & 35.05 & 36.78 & 43.04 & 45.05 & 47.29 & 46.27 & 45.41 & 6.88 & 7.13 & 8.00 & 7.62 & 7.41 & 9.05 & 9.59 & 10.90 & 10.67 & 10.05 \\
\hline Varieties & 0 & 37.43 & 39.96 & 36.23 & 37.69 & 37.83 & 50.20 & 53.01 & 51.40 & 50.92 & 51.38 & 8.32 & 9.36 & 9.82 & 8.81 & 9.08 & 9.06 & 10.47 & 10.83 & 10.34 & 10.17 \\
\hline Mean & & 35.46 & 36.37 & 36.79 & 34.76 & 35.84 & 44.82 & 46.97 & 47.09 & 47.94 & 46.70 & 7.30 & 7.80 & 8.27 & 7.93 & 7.83 & 8.70 & 9.49 & 10.13 & 10.12 & 9.61 \\
\hline \multicolumn{22}{|c|}{ L.S.D at 0.05 level for: } \\
\hline \multicolumn{2}{|l|}{ (A) } & & & & & 0.63 & & & & & 2.40 & & & & & 0.19 & & & & & 0.14 \\
\hline \multicolumn{2}{|l|}{ (B) } & & & & & 1.89 & & & & & 2.24 & & & & & 0.35 & & & & & 0.40 \\
\hline \multicolumn{2}{|c|}{ Varieties (C) } & & & & & N.S & & & & & N.S & & & & & 0.40 & & & & & 0.44 \\
\hline \multicolumn{2}{|c|}{$\mathrm{A} \times \mathrm{B}$} & & & & & 2.68 & & & & & 3.16 & & & & & 0.49 & & & & & 0.56 \\
\hline \multicolumn{2}{|c|}{$\mathrm{A} \times \mathrm{C}$} & & & & & N.S & & & & & N.S & & & & & N.S & & & & & N.S \\
\hline \multicolumn{2}{|c|}{$\mathrm{B} \times \mathrm{C}$} & & & & & N.S & & & & & N.S & & & & & N.S & & & & & N.S \\
\hline \multicolumn{2}{|c|}{$\mathrm{A} \times \mathrm{B} \times \mathrm{C}$} & & & & & N.S & & & & & N.S & & & & & N.S & & & & & N.S \\
\hline
\end{tabular}


composition had been reported by Al-Lboboudy et al., (2008).

The combined interactions over the two seasons of the studied factors showed insignificantly effect on the juice and syrup extractions (\%) of sweet sorghum plants except the interaction between irrigation water resources and gibberellic acid concentration.

\section{Purity and sucrose \%}

Data in Table (6) revealed that fish farm waste water resource was significantly less efficient than well ground irrigation water on purity and sucrose percentage in the two seasons. Where, the values of purity and sucrose $\%$ under well ground water were more than fish farm waste irrigation water for purity by (7.58 and $7.83 \%)$ and sucrose\% by (1.30 and 1.38\%) in 2018 and 2019 seasons, respectively. These results are in agreement with that of Abdelraouf and Hoballah, 2014.

Results in Table 6 revealed a significant decrease in purity and sucrose $\%$ by increasing gibberellic acid $\left(\mathrm{GA}_{3}\right)$ concentration from zero up to $400 \mathrm{ppm}$ in both seasons. The decrease in the 2018 and 2019 seasons amounted to (5.20 and 4.81) and (1.18 and 1.17) \% for purity and sucrose $\%$ as $\mathrm{GA}_{3}$ concentrations decreased from 400 to zero ppm, respectively.

Purity and sucrose (Pol) is the most important feature of juice quality in sugar crops including sweet sorghum. Significant variation among the used sweet sorghum varieties in purity $\%$ and sucrose $\%$ have been detected in both seasons Table (6). Ramada variety gave the highest purity\% and sucrose \% values (33.66 and $36.38 \%$ ) and (9.29 and 13.55\%) in 2018 and 2019 seasons, successively. Meantime, AGSC3 variety exhibited the lowest purity $\%$ and sucrose $\%$ value $(31.84$ and $34.21 \%)$ and $(8.77$ and $13.02 \%)$ in the first and second season, respectively. Worth to mention that sweet sorghum with low sucrose $\%$ and high reducing sugars content are more suitable for syrup production and low fermentable industries due to non or less sucrose crystallization takes place through processing (Parvatikar and Manjunath, 1991). Ma et al., (1992) reported that significant linear correlation between the brix and total sugar content of the juice and the total sugar content could therefore be calculated from brix. In this connection under Egyptian conditions Abd ElKarim et al., (1999) and Allam et al., (2001) mentioned to marked variation in brix values among sorghum varieties.

Sucrose and purity\% was significantly influenced by the interaction between water resources and gibberellic acid concentrations in the $1^{\text {st }}$ and $2^{\text {nd }}$ seasons (Table 6). The heights mean values of purity\% were obtained under well irrigation water and zero $\mathrm{GA}_{3}$. Whereas the lowest ones were obtained under fish waste farm water and 400 ppm $\mathrm{GA}_{3}$ during both seasons of the study. However, insignificant variance in purity \% was detected between water resources types under study under different varieties $(\mathrm{A} \times \mathrm{C})$. On the contrary, the values of sucrose $\%$ were significantly affected between water resources under different varieties $(A \times C)$ in both seasons.

Purity and sucrose \% significantly affected by the interaction between gibberellic acid concentrations and varieties $(\mathrm{B} \times \mathrm{C})$ (Table 6) in the second season for sucrose and both seasons for purity. Among the studied traits purity $\%$ in both seasons and sucrose $\%$ in the first season only was affected significantly by the interaction among water resources, gibberellic acid concentrations and varieties $(\mathrm{A} \times \mathrm{B} \times \mathrm{C})$ (Table 6). The highest values of purity $\%$ and sucrose $\%$ were produced from application of well irrigation water and zero ppm of gibberellic acid with Ramada variety.

\section{Gross and juice water use efficiency $\left(\mathrm{kg} / \mathrm{m}^{3}\right)$}

Irrigation plants by fish farm waste water had a clear trend with respect to its effect on water use efficiency (WUE) of gross and juice yield in both seasons (Table 7). Where, applying fish farm waste water increased water use efficiency (WUE) of gross yield by (44.22 and $54.92 \%$ ) and water use efficiency (WUE) of juice yield (58.39 and 76.94\%) during 2018 and 2019 seasons, respectively compared to the irrigation by well ground water.

Results in Table (7) cleared that mean values of water use efficiency based on gross and juice yields were significantly increased by increasing $\mathrm{GA}_{3}$ concentrations from 0 to $400 \mathrm{ppm}$ in the two growing seasons. increasing the amount of concentration from zero to 200 and $400 \mathrm{ppm} \mathrm{GA}_{3}$ significantly increased WUE of gross yield by 1.47 and $3.23 \mathrm{~kg} / \mathrm{m}^{3}$ in the $1^{\text {st }}$ season and by 1.90 and $4.02 \mathrm{~kg} / \mathrm{m}^{3}$ in the $2^{\text {nd }}$ season, while the increase in WUE of juice yield amounted to 0.44 and $0.61 \mathrm{~kg} / \mathrm{m}^{3}$ in the $1^{\text {st }}$ season and 0.23 and 0.55 $\mathrm{kg} / \mathrm{m}^{3}$ in the $2^{\text {nd }}$ season, respectively.

Water use efficiency of gross and juice yield $\left(\mathrm{kg} / \mathrm{m}^{3}\right)$ diferred significantly among varieties in both seasons (Table 7). AGSC3 exhibited the highest WUE gross $(8.53$ and $11.79 \mathrm{~kg} / \mathrm{m}^{3}$ ) in the first and second seasons, respectively.

Meanwhile, the highest $\mathrm{WUE}_{\text {juice }}$ in first season was of AGSC3 $\left(2.36 \mathrm{~kg} / \mathrm{m}^{3}\right)$ followed by Gkahron (2.22 $\left.\mathrm{kg} / \mathrm{m}^{3}\right)$ and Gukorcirok $\left(2.16 \mathrm{~kg} / \mathrm{m}^{3}\right)$, the variety next in order was Ramada $\left(1.94 \mathrm{~kg} / \mathrm{m}^{3}\right)$. Also, in the second season, AGSC3 exhibited the highest value $\left(3.69 \mathrm{~kg} / \mathrm{m}^{3}\right)$ followed by Gkahron $\left(3.58 \mathrm{~kg} / \mathrm{m}^{3}\right)$ and Gukorcirok (3.51 
Table 6. Purity and sucrose (\%) of four sweet sorghum varieties under the effect of different irrigation sources and gibberellic acid (GA3) concentrations during 2018 and 2019 seasons

\begin{tabular}{|c|c|c|c|c|c|c|c|c|c|c|c|c|c|c|c|c|c|c|c|c|c|}
\hline \multirow{3}{*}{$\begin{array}{l}\text { Sources } \\
\text { of } \\
\text { irrigation } \\
\text { (A) }\end{array}$} & \multirow[b]{3}{*}{$\begin{array}{c}\mathbf{G A}_{3} \\
\text { Conc* } \\
(\mathbf{p p m}) \\
\text { (B) }\end{array}$} & \multicolumn{10}{|c|}{ Purity (\%) } & \multicolumn{10}{|c|}{ Sucrose $(\%)$} \\
\hline & & \multicolumn{5}{|c|}{2018} & \multicolumn{5}{|c|}{2019} & \multicolumn{5}{|c|}{2018} & \multicolumn{5}{|c|}{2019} \\
\hline & & 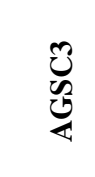 & 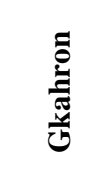 & 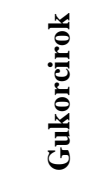 & 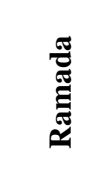 & 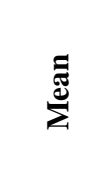 & $\underset{Z}{\mathscr{Z}}$ & 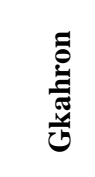 & 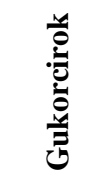 & 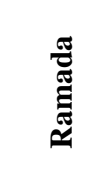 & 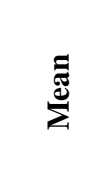 & $\underset{\Downarrow}{\mathscr{W}}$ & 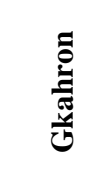 & 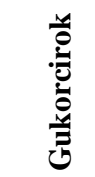 & 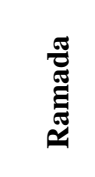 & $\sum_{\Sigma}^{\mathbb{E}}$ & 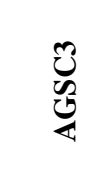 & 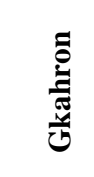 & 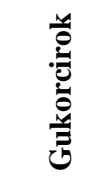 & 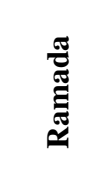 & 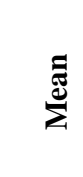 \\
\hline \multirow{3}{*}{ Aquaculture } & 400 & 25.50 & 26.13 & 26.94 & 28.05 & 26.66 & 27.80 & 28.73 & 29.24 & 30.35 & 29.03 & 8.08 & 7.59 & 7.84 & 8.03 & 7.89 & 12.34 & 11.85 & 12.10 & 12.29 & 12.15 \\
\hline & 200 & 27.29 & 28.09 & 29.83 & 30.54 & 28.94 & 29.59 & 30.39 & 32.13 & 32.84 & 31.24 & 8.25 & 8.49 & 8.51 & 8.51 & 8.44 & 12.51 & 12.75 & 12.77 & 12.77 & 12.70 \\
\hline & 0 & 31.24 & 31.18 & 31.55 & 32.00 & 31.49 & 33.54 & 33.48 & 33.85 & 34.30 & 33.79 & 8.56 & 8.63 & 8.81 & 8.82 & 8.71 & 12.79 & 12.89 & 13.07 & 13.08 & 12.96 \\
\hline \multirow[t]{2}{*}{ Mean } & & 28.01 & 28.47 & 29.44 & 30.20 & 29.03 & 30.31 & 30.87 & 31.74 & 32.50 & 31.35 & 8.30 & 8.24 & 8.39 & 8.45 & 8.34 & 12.55 & 12.50 & 12.65 & 12.71 & 12.60 \\
\hline & 400 & 31.62 & 33.53 & 34.35 & 34.27 & 33.44 & 33.92 & 35.83 & 36.91 & 39.11 & 36.44 & 8.86 & 8.90 & 8.99 & 9.02 & 8.94 & 13.12 & 13.16 & 13.25 & 13.28 & 13.20 \\
\hline \multirow[t]{2}{*}{ Well } & 200 & 36.81 & 37.27 & 38.23 & 37.23 & 37.39 & 39.57 & 39.57 & 40.53 & 39.53 & 39.80 & 9.16 & 9.42 & 9.54 & 9.87 & 9.50 & 13.42 & 13.68 & 14.80 & 14.13 & 14.01 \\
\hline & 0 & 38.56 & 37.83 & 39.80 & 39.85 & 39.01 & 40.86 & 40.13 & 42.10 & 42.15 & 41.31 & 9.69 & 10.32 & 10.39 & 11.46 & 10.47 & 13.95 & 14.58 & 14.65 & 15.72 & 14.73 \\
\hline \multicolumn{2}{|c|}{ Mean } & 35.66 & 36.21 & 37.46 & 37.12 & 36.61 & 38.12 & 38.51 & 39.85 & 40.26 & 39.18 & 9.24 & 9.55 & 9.64 & 10.12 & 9.64 & 13.50 & 13.81 & 14.23 & 14.38 & 13.98 \\
\hline $\mathrm{GA}_{3}$ & 400 & 28.56 & 29.83 & 30.65 & 31.16 & 30.05 & 30.86 & 32.28 & 33.08 & 34.73 & 32.74 & 8.47 & 8.25 & 8.42 & 8.53 & 8.41 & 12.73 & 12.51 & 12.68 & 12.79 & 12.67 \\
\hline$x$ & 200 & 32.05 & 32.68 & 34.03 & 33.89 & 33.16 & 34.58 & 34.98 & 36.33 & 36.19 & 35.52 & 8.71 & 8.96 & 9.03 & 9.19 & 8.97 & 12.97 & 13.22 & 13.79 & 13.45 & 13.35 \\
\hline Varieties & 0 & 34.90 & 34.51 & 35.68 & 35.93 & 35.25 & 37.20 & 36.81 & 37.98 & 38.23 & 37.55 & 9.13 & 9.48 & 9.60 & 10.14 & 9.59 & 13.37 & 13.74 & 13.86 & 14.40 & 13.84 \\
\hline Mean & & 31.84 & 32.34 & 33.45 & 33.66 & 32.82 & 34.21 & 34.69 & 35.79 & 36.38 & 35.27 & 8.77 & 8.89 & 9.01 & 9.29 & 8.99 & 13.02 & 13.15 & 13.44 & 13.55 & 13.29 \\
\hline \multicolumn{22}{|c|}{ L.S.D at 0.05 level for: } \\
\hline \multicolumn{2}{|l|}{ (A) } & & & & & 0.37 & & & & & 0.47 & & & & & 0.11 & & & & & 0.23 \\
\hline \multicolumn{2}{|c|}{ (B) } & & & & & 0.42 & & & & & 0.30 & & & & & 0.11 & & & & & 0.15 \\
\hline \multicolumn{2}{|c|}{ Varieties $(\mathrm{C})$} & & & & & 0.39 & & & & & 0.27 & & & & & 0.08 & & & & & 0.16 \\
\hline \multicolumn{2}{|c|}{$\mathrm{A} \times \mathrm{B}$} & & & & & 0.30 & & & & & 0.42 & & & & & 0.16 & & & & & 0.21 \\
\hline \multicolumn{2}{|c|}{$\mathrm{A} \times \mathrm{C}$} & & & & & N.S & & & & & N.S & & & & & 0.11 & & & & & 0.22 \\
\hline \multicolumn{2}{|c|}{$\mathrm{B} \times \mathrm{C}$} & & & & & N.S & & & & & 0.46 & & & & & 0.14 & & & & & 0.27 \\
\hline \multicolumn{2}{|c|}{$\mathrm{A} \times \mathrm{B} \times \mathrm{C}$} & & & & & 0.68 & & & & & 0.66 & & & & & 0.20 & & & & & N.S \\
\hline
\end{tabular}


Table 7. Gross and juice water use efficiency $\left(\mathrm{kg} / \mathrm{m}^{3}\right)$ of four sweet sorghum varieties under the effect of different irrigation resources and gibberellic acid (GA3) concentrations during 2018 and 2019 seasons

\begin{tabular}{|c|c|c|c|c|c|c|c|c|c|c|c|c|c|c|c|c|c|c|c|c|c|}
\hline \multirow{3}{*}{$\begin{array}{l}\text { Sources } \\
\text { of } \\
\text { irrigation } \\
\text { (A) }\end{array}$} & \multirow{3}{*}{$\begin{array}{c}\mathbf{G A}_{3} \\
\text { Conc* } \\
(\mathbf{p p m}) \\
(\mathbf{B})\end{array}$} & \multicolumn{10}{|c|}{ WUEgross } & \multicolumn{10}{|c|}{ WUE $_{\text {juice }}$} \\
\hline & & \multicolumn{5}{|c|}{2018} & \multicolumn{5}{|c|}{2019} & \multicolumn{5}{|c|}{2018} & \multicolumn{5}{|c|}{2019} \\
\hline & & 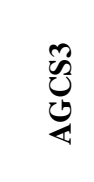 & 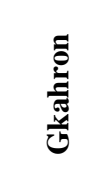 & 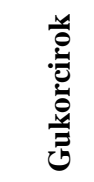 & 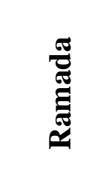 & 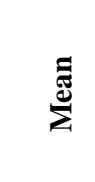 & 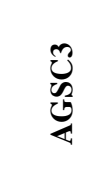 & 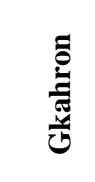 & 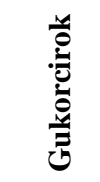 & 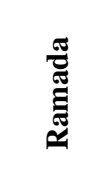 & 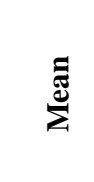 & $\underset{\mho}{\mathscr{U}}$ & 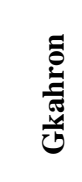 & 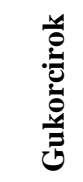 & 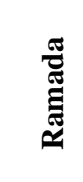 & $\sum_{\Sigma}^{\mathbb{E}}$ & 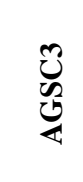 & 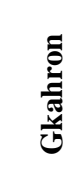 & 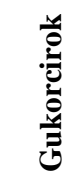 & 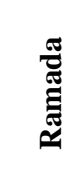 & $\sum_{\text {¿ }}^{\tilde{J}}$ \\
\hline \multirow{3}{*}{ Aquaculture } & 400 & 14.53 & 13.31 & 13.00 & 12.22 & 13.27 & 18.09 & 16.87 & 16.56 & 15.78 & 16.83 & 2.94 & 2.83 & 3.03 & 2.84 & 2.91 & 4.18 & 4.11 & 4.30 & 4.16 & 4.19 \\
\hline & 200 & 11.35 & 11.54 & 9.92 & 9.79 & 10.65 & 14.91 & 15.11 & 13.48 & 14.20 & 14.43 & 3.27 & 2.94 & 2.76 & 2.53 & 2.88 & 4.34 & 4.01 & 3.88 & 3.63 & 3.97 \\
\hline & 0 & 9.54 & 8.98 & 8.14 & 7.36 & 8.50 & 12.08 & 11.83 & 11.26 & 10.43 & 11.40 & 2.56 & 2.53 & 2.38 & 2.21 & 2.42 & 4.01 & 4.06 & 4.06 & 3.12 & 3.81 \\
\hline \multirow[t]{2}{*}{ Mean } & & 11.81 & 11.28 & 10.35 & 9.79 & 10.81 & 15.03 & 14.60 & 13.77 & 13.47 & 14.22 & 2.93 & 2.77 & 2.72 & 2.53 & 2.74 & 4.18 & 4.06 & 4.08 & 3.64 & 3.99 \\
\hline & 400 & 6.05 & 5.74 & 5.40 & 5.40 & 5.65 & 10.51 & 9.20 & 8.88 & 8.54 & 9.28 & 2.22 & 1.89 & 2.14 & 1.56 & 1.95 & 3.58 & 3.43 & 3.24 & 3.59 & 3.46 \\
\hline \multirow[t]{2}{*}{ Well } & 200 & 5.23 & 4.80 & 4.80 & 4.17 & 4.75 & 7.94 & 7.52 & 7.52 & 6.88 & 7.46 & 1.70 & 1.84 & 1.59 & 1.43 & 1.64 & 3.00 & 3.12 & 3.02 & 2.99 & 3.03 \\
\hline & 0 & 4.51 & 3.97 & 3.72 & 3.63 & 3.96 & 7.22 & 6.69 & 6.43 & 6.35 & 6.67 & 1.46 & 1.25 & 1.09 & 1.09 & 1.22 & 3.05 & 2.74 & 2.56 & 2.56 & 2.73 \\
\hline \multicolumn{2}{|l|}{ Mean } & 5.26 & 4.84 & 4.64 & 4.40 & 4.78 & 8.56 & 7.80 & 7.61 & 7.26 & 7.81 & 1.79 & 1.66 & 1.60 & 1.36 & 1.60 & 3.21 & 3.10 & 2.94 & 3.05 & 3.07 \\
\hline $\mathrm{GA}_{3}$ & 400 & 10.29 & 9.52 & 9.20 & 8.81 & 9.46 & 14.30 & 13.03 & 12.72 & 12.16 & 13.06 & 2.58 & 2.36 & 2.58 & 2.20 & 2.43 & 3.88 & 3.77 & 3.77 & 3.88 & 3.82 \\
\hline$x$ & 200 & 8.29 & 8.17 & 7.36 & 6.98 & 7.70 & 11.43 & 11.31 & 10.50 & 10.54 & 10.94 & 2.48 & 2.39 & 2.17 & 1.98 & 2.26 & 3.67 & 3.57 & 3.45 & 3.31 & 3.50 \\
\hline Varieties & 0 & 7.02 & 6.47 & 5.93 & 5.50 & 6.23 & 9.65 & 9.26 & 8.85 & 8.39 & 9.04 & 2.01 & 1.89 & 1.74 & 1.65 & 1.82 & 3.53 & 3.40 & 3.31 & 2.84 & 3.27 \\
\hline Mean & & 8.53 & 8.06 & 7.50 & 7.10 & 7.80 & 11.79 & 11.20 & 10.69 & 10.36 & 11.01 & 2.36 & 2.22 & 2.16 & 1.94 & 2.17 & 3.69 & 3.58 & 3.51 & 3.34 & 3.53 \\
\hline \multicolumn{22}{|c|}{ L.S.D at 0.05 level for: } \\
\hline \multicolumn{2}{|l|}{ (A) } & & & & & 0.26 & & & & & 0.26 & & & & & 0.22 & & & & & 0.17 \\
\hline \multicolumn{2}{|l|}{ (B) } & & & & & 0.22 & & & & & 0.22 & & & & & 0.18 & & & & & 0.15 \\
\hline \multicolumn{2}{|c|}{ Varieties $(\mathrm{C})$} & & & & & 0.20 & & & & & 0.20 & & & & & 0.12 & & & & & 0.13 \\
\hline \multicolumn{2}{|c|}{$\mathrm{A} \times \mathrm{B}$} & & & & & 0.30 & & & & & 0.31 & & & & & 0.25 & & & & & N.S \\
\hline \multicolumn{2}{|c|}{$\mathrm{A} \times \mathrm{C}$} & & & & & N.S & & & & & N.S & & & & & 0.17 & & & & & N.S \\
\hline \multicolumn{2}{|c|}{$\mathrm{B} \times \mathrm{C}$} & & & & & N.S & & & & & N.S & & & & & N.S & & & & & N.S \\
\hline \multicolumn{2}{|c|}{$\mathrm{A} \times \mathrm{B} \times \mathrm{C}$} & & & & & N.S & & & & & N.S & & & & & 0.29 & & & & & N.S \\
\hline
\end{tabular}


$\mathrm{kg} / \mathrm{m}^{3}$ ). while, Ramada variety gave the lowest WUE of juice yield $\left(3.34 \mathrm{~kg} / \mathrm{m}^{3}\right)$ in $2^{\text {nd }}$ season.

WUE of gross yield was significantly affected by the interaction between water resources and gibberellic acid application in the first and second seasons. The highest WUE of gross yield $\left(13.27\right.$ and $\left.16.83 \mathrm{~kg} / \mathrm{m}^{3}\right)$ resulted from aquaculture water resources with $400 \mathrm{ppm}$ of gibberellin concentration in the $1^{\text {st }}$ and $2^{\text {nd }}$ seasons, respectively. While, the lowest WUE of gross yield (3.96 and $6.67 \mathrm{~kg} / \mathrm{m}^{3}$ ) resulted from well water resources without gibberellin application in the $1^{\text {st }}$ and $2^{\text {nd }}$ seasons, respectively.

Water use efficiency of juice yield significantly affected by the interaction between water resources and gibberellic acid concentrations $(\mathrm{A} \times \mathrm{B})$, as well as between water resources and varieties $(A \times B \times C)$, also the interactions among the three factors under study are significantly affected on WUE of yield only in the first season. Applying fish farm waste water and $400 \mathrm{ppm}$ of gibberellic acid concentrations gave the highest and significant value of WUE juice yield $\left(2.91 \mathrm{~kg} / \mathrm{m}^{3}\right)$ in 2017 season. Also, the highest WUE of juice yield was 2.93 $\mathrm{kg} / \mathrm{m}^{3}$ resulted from applying fish farm waste water irrigation on AGSC3 variety in 2017 season. While, the highest trait value $\left(3.27 \mathrm{~kg} / \mathrm{m}^{3}\right)$ resulted under the combination among fish farm water waste $+200 \mathrm{ppm}$ $\mathrm{GA}_{3}$ concentration + AGSC3 variety.

\section{CONCLUSIONS}

The present study indicated that yield parameters and water use efficiency of sweet sorghum plants were highly enhanced by cultivating AGSC3 variety using fish farm waste water than ground water resource. Foliar spraying the plants by $400 \mathrm{ppm}$ of gibberellic acid increased yield of sweet sorghum, but also enhanced water use efficiency in Wadi El-Natrun region. It was concluded that the use of waste water of fish farms instead of well water for irrigation of plants could help to achieve higher yields, while using less irrigation water and less chemical fertilizers. Additional benefits are less drainage to the drainage network and higher income for farmers.

\section{REFERENCE}

A.O.A.C. 1995. Association of Official Analytical Chemists. Official Methods of Analysis. $16^{\text {th }}$ ed., AOAC International, Washington, D.C., USA.

Abd El-Karim, H.A., T.S. El-Ammari and G. B. Maria 1999. Evaluation of some sweet sorghum cultivars for syrup and biomass production. J. Agric. Sci. Mansoura Univ. 24(10): 528-559.
Abdelraouf, R.E. and E.M.A. Hoballah. 2014. Impact of irrigation systems, fertigation rates and using drainage water of fish farms in irrigation of potato under arid regions conditions. Int. J. Sci. Res. Agric. Sci. 1(5): 67-79.

Abdelraouf, R.E. and R. Ragab. 2017. The benefit of using drainage water of fish farms for irrigation field and modeling study using the saltmed model. Irrig. Drain. 66: 758-772.

Abo-El Wafa, A.M. and A.S. Abo-El Hamd. 2001. Evaluation of some sweet sorghum varieties under different plant populations in Upper Egypt. Minia J. Agric., Res. and Develop. 21(3): 475- 492.

Al-Labobody, A.H., A.M. Abd El-Razek and S.Y. Besheit. 2008. Evaluation of some sweet sorghum varieties Sorghum bicolor, L, Moench under two sowing dates. Zagazig J. Agric. Res. 35(1): 1-18.

Allam, S.M., A.M. Nassar, A.M. Abo El-Wafa and M.K. Ali. 2001. Quality and processing evaluation of some sweet sorghum varieties and their potentialities for syrup and ethanol production. J. Agric. Sci. Mansoura Univ. 26(1): $1-12$.

Almodares, A., M. Usofzadeh and M. Daneshvar. 2013. Effect of nitrogen and ethephon on growth parameters, carbohydrate contents and bioethanol production from sweet sorghum. Sugar Tech. 15: 300-304.

Datta, S.A. P., P.S. Rao, C.H.R. Reddy and B.V.S. Reddy. 2012. Innovative use of sweet sorghum juice in the beverage industry. Int. Food. Res. J. 194:1361-1366

Dželetović, Z.S. and N.G. Djordje. 2015. Effect of nitrogen on the distribution of biomass and element composition of the root system of Miscanthus $\times$ Giganteus. Arch. Biol. Sci. Belgrade. 67(2): 547-560.

Ebong V. and M. Ebong. 2006. Demand for fertilizer technology by smallholder crop farmers for sustainable agricultural development in Akwa, Ibom state, Nigeria. Int. J. Agric. Bio. 8 (6): 728- 731.

El-Geddawy, D.I. H., N. M. M. Awad, Sahar and M. I. Moustafa. 2014. Lighting spot around yield and technological characteristics of some sweet sorghum varieties. Int. J. Curr. Microbiol. App. Sci. 3(4): 843-850.

Fedoroff, N.V., D.S. Battisti, R.N. Beachy, P.J.M. Cooper, D.A. Fischhoff, C.N. Hodges, V.C. Knauf, D.B. Lobell, B.J. Mazur, D. Molden, M.P. Reynolds, P.C. Ronald, M.W. Rosegrant, P.A. Sanchez, A. Vonshak, and J.K. Zhu. 2010. Radically rethinking agriculture for the $21^{\text {st }}$ century. Science. 327(5967): 833-834.

Godsey, C.B., J. Linneman, D. Bellmer and R. Huhnke. 2012. Developing row spacing and planting density recommendations for rainfed sweet sorghum production in the southern plains. Agron. J. 104: 280-286.

Gomez, K.A. and A.A. Gomez. 1984. Statistical Procedures for Agric. Res., $2^{\text {nd }}$ ed. John Willey and Sons, New York. pp.680.

Gupta, R.1., S.K. Chakrabarty. 2013. Gibberellic acid in plant: still a mystery unresolved. Plant Signal Behav. 8(9). Pp: 2550 . 
Israelsen, O.W. and V.E. Hansen. 1962. Irrigation Principles and Practices. $3^{\text {rd }}$ ed., John Willey and Sons Inc. New York.

Jensen, M.E. 1983. Design and operation of farm irrigation systems. ASAE, Michigan, USA. Pp. 827.

Leite, G.H.P., C.A.C. Crusciol and M.A. Silva. 2011. Desenvolvimento produtividade da cana-de-açúcar após aplicação de reguladores vegetais em meio de safra. Semina: Ciências Agrárias. 32: 129-138.

Ma, Z.H., D. Li and X.B. Nimg. 1992. Study on brix degree, total sugar content and their relationship in juice of sweet sorghum stem. J. Shenyang Agric. Univ. China. 23(3):187-191.

Milne, R.J., C.S. Byrt, J.W. Patrick and C.P.L. Grof. 2013. Are sucrose transporter expression profiles linked with patterns of biomass partitioning in Sorghum phenotypes? Frontiers in Plant Sci. 4: 1-12.

Mokadem, S.A., M.A. Salem and M. T. Nour El. Hoda. 1999. Evaluation of yield and its components as well as syrup reduction of some sweet sorghum varieties Sorghum bicolor L. Moench grown under middle Egypt environmental conditions. Minia J. Agric. Res. and Develop. 19: 207-218.

Moursy، M.A.M. 2018. Influence of Agri-aquaculture and seed treatment techniques on sugar beet crop. J. Soil. Sci. and Agric. Eng., Mansoura Univ. 9(1): 63-68.
Parvatikar, S.R. and T.V. Manjunath. 1991. Alternate uses of sorghum sweet sorghums a new prospectus for juicy stalks and grain yields. J. Maharashtra Agric. Univ. India. 6(3): 352-354.

Ray, L. I.P., P.K. Panigrahi, S. Moulick, B.C. Mal, B.S. Das and N. Bag. 2010. Integrated aquaculture within irrigation options- an economic analysis in indian. context. Int. J. Sci. Nature. 1(2): 253-258.

Saleh, G.G. 2004. Growth and yield of biofertilized sweet sorghum under stress ecological conditions. Ph.D. Thesis, Environ. Sci. Dept. Agric. Sci. (Agron.), Ain-Shams Univ. Egypt.

Supriya, M. A.V., V.A. Umakanth, Tonapi, R. Sh. and K. Sh. Manoj. 2017. sorghum as biofuel feedstock: recent advances and available resources. Biotechnol. Biofuels. 10:146.

Whitfield, M.B., M.S. Chinn and M.W. Veal. 2012. Processing of materials derived from sweet sorghum for biobased products. Ind. Crop. Pro. 37: 362-375.

Value-Chain Analysis of Aquaculture. 2011. Value-chain analysis of Egyptian aquaculture. World Fish Center. Pp: 78 


\section{الملخص العربي}

تأثير حامض الجبرليك ومصادر الري المختلفة على الصفات الخضرية والجودة والمحصول لبعض اصناف الأرة السكرية المنزرعة بالأراضي حديثة الاستصلاح الرئ

محمد سعيد القاضي، سمر عبد العاطي محمد حلمى و مها محمد الزيني

بينما تفوق الري بالمياه الجوفية في نسبة العصير

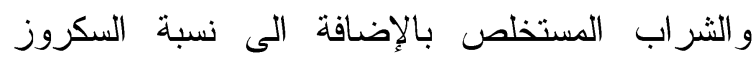
و النقاوة مقارنة بالري بنواتج المزارع السمكية خلال

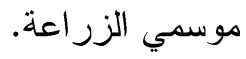

r-ز ادت صفات النمو و المحصول وكفاءة استخدام المياه

لنباتات الذرة السكرية معنويا بزيادة تركيزات حامض

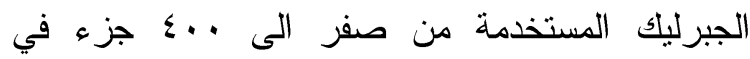
المليون، بينما انخفضت صفات الجودة.

r-تقوق الصنف AGSC3 معنويا في صفات النمو و المحصول وكفاءة استخدام المياه مقارنة بباقي الاصناف، بينما تفوق معنويا الصنف Ramada في صفات الجودة خلال موسمي النمو تحت الدراسة.
أقيمت تجربة حقلية في أراضي رملية بمنطقة وادى

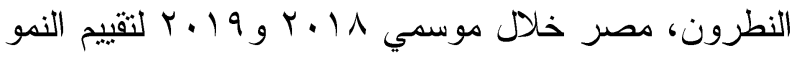

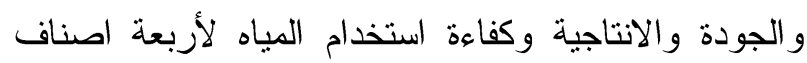
من الذرة السكرية تحت نأثير نوعين من مصادر الري (الري بنواتج المزارع السمكية والري بالمياه الجوفية) والرش بثلاث تركيز ات من حامض الجبرليك (صفر و . . r

$$
\text { و و . . عـ جزء في المليون). }
$$

ا-تفوق معنويا الري بنو اتج المزارع السمكية مقارنة بالري

بالمياه الجوفية في صفات النمو الخضرية (طول وقطر بلري الساق(سم) و المحصول (المحصول الكلى ومحصول السيقان (طن/الفدان)) وكفاءة استخدام المياه (كجم/2)؛ 